\title{
Silicon and agar on in vitro development of cockscomb (Amaranthaceae)
}

\author{
Franscinely Aparecida de Assis(1), Genaina Aparecida de Souza ${ }^{(2)}$, \\ Gabrielen de Maria Gomes Dias ${ }^{(3)}$, Gleice Aparecida de Assis ${ }^{(4)}$, Filipe Almendagna Rodrigues ${ }^{(3)}$, \\ Moacir Pasqual( ${ }^{(3)}$, Bárbara Nogueira Souza $\operatorname{Costa}^{(3)}$ and Fábio Janoni Carvalho ${ }^{(4)}$
}

\begin{abstract}
(1)Centro Universitário de Goiatuba (UniCerrado), Rodovia GO 320, Jardim Santa Paula, CEP 75600-000 Goiatuba, GO, Brazil. E-mail: franscinelyagronomia@yahoo.com.br (2)Universidade Federal de Viçosa, Departamento de Biologia Vegetal, Avenida Purdue, s/no, CEP 36570-000Viçosa,MG,Brazil.E-mail:genainasouza@yahoo.com.br ${ }^{(3)}$ UniversidadeFederaldeLavras, DepartamentodeAgricultura,Campus Universitário, Caixa Postal 3037, CEP 37200-000 Lavras, MG, Brazil. E-mail: gabriellen@gmail.com, filipealmendagna@yahoo.com.br, mpasqual@dag.ufla.br, babinogueiraagro@hotmail.com ${ }^{(4)}$ Universidade Federal de Uberlândia, Campus Monte Carmelo, Rodovia LMG 746, Km 1, Araras, CEP 38500-000 Monte Carmelo, MG, Brazil. E-mail: gaassis@iciag.ufu.br, fabiojanoni@hotmail.com
\end{abstract}

Abstract - The objective of this work was to evaluate the effect of silicon and agar concentrations on cockscomb (Celosia cristata) (Amaranthaceae) development in vitro. Phytotechnical, anatomical, and ultrastructural analyses were carried out in a completely randomized design, in a $4 \times 3$ factorial arrangment, with four silicic acid concentrations $\left(0.0,0.5,1.0\right.$, and $\left.1.5 \mathrm{~g} \mathrm{~L}^{-1}\right)$ and three agar concentrations $\left(5.5,8.0\right.$, and $\left.10.5 \mathrm{~g} \mathrm{~L}^{-1}\right)$, totaling 12 treatments with seven replicates. Celosia cristata explants were inoculated in vitro in a Murashige \& Skoog (MS) culture medium, with $30 \mathrm{~g} \mathrm{~L}^{-1}$ sucrose. The analyses were conducted 30 days after inoculation. Phytotechnical traits improve with agar concentration of $8.0 \mathrm{~g} \mathrm{~L}^{-1}$, and the association of this concentration with $1.0 \mathrm{~g} \mathrm{~L}^{-1}$ silicon also contributes to the improvement of anatomical attributes, especially of leaf blade width and thickness of the palisade and spongy parenchyma, which contributes to the development of C. cristata. None of the evaluated combinations of agar and silicon contributes to Si deposition on the foliar epidermis of this ornamental species.

Index terms: Celosia cristata, gelling agent, micropropagation, ornamental plant, silicic acid.

\section{Silício e ágar no desenvolvimento in vitro de crista-de-galo (Amaranthaceae)}

\begin{abstract}
Resumo - O objetivo deste trabalho foi avaliar o efeito de concentrações de silício e ágar no desenvolvimento in vitro de crista-de-galo (Celosia cristata) (Amaranthaceae). Análises fitotécnicas, anatômicas e ultraestruturais foram conduzidas em delineamento inteiramente casualizado, em arranjo fatorial $4 \times 3$, com quatro concentrações de ácido silícico $\left(0,0,0,5,1,0\right.$ e $\left.1,5 \mathrm{~g} \mathrm{~L}^{-1}\right)$ e três de ágar $\left(5,5,8,0\right.$ e $\left.10,5 \mathrm{~g} \mathrm{~L}^{-1}\right)$, no total de 12 tratamentos com sete repetições. Explantes de $C$. cristata foram inoculados in vitro em meio de cultura Murashige \& Skoog (MS ), com $30 \mathrm{~g} \mathrm{~L}^{-1}$ de sacarose. As análises foram realizadas 30 dias após a inoculação. As características fitotécnicas melhoram com a concentração de ágar a $8,0 \mathrm{~g} \mathrm{~L}^{-1}$, e a associação dessa concentração com $1,0 \mathrm{~g} \mathrm{~L}^{-1}$ de silício contribui ainda para a melhoria dos atributos anatômicos, principalmente a largura do limbo foliar e a espessura dos parênquimas paliçádico e esponjoso, o que colabora para o desenvolvimento de $C$. cristata. Nenhuma das combinações avaliadas de silício e ágar contribui para deposição de Si na epiderme foliar dessa espécie ornamental.
\end{abstract}

Termos para indexação: Celosia cristata, agente geleificante, micropropagação, planta ornamental, ácido silícico.

\section{Introduction}

Celosia cristata L., commonly known as cockscomb, is an ornamental plant that belongs to the Amaranthaceae family, frequently found in residential homes. This species is relevant both medically, due to its therapeutic proprieties, mainly focused on healing (Gonçalves \& Pasa, 2015), and economically, as cut flowers (Tlahuextl-Tlaxcalteca et al., 2005); for this reason, studies directed to propagation are intensified, aiming to obtain plants during all year.

In general, this plant exhibits sexual propagation since its seeds do not present dormancy when they are originated from mature fruits (Ferreira et al., 2012). However, the micropropagation of $C$. cristata, performed with explants, is faster than the conventional 
sexual propagation, allowing the production of a large number of clones, regardless of the period of the year, with genetic-sanitary quality, besides the possibility of in vitro flowering (Taha \& Wafa, 2012). In order to obtain plants with higher vigor and uniformity, which are characteristics highly desirable in floriculture, this technique is being used for several species of the genus Celosia (Bodhipadma et al., 2010; Daud et al., 2011).

Available protocols for micropropagation of $C$. cristata have been elaborated and show that the sprouts from 12-days-old seedlings, facilitate the regeneration in vitro when subjected to MS medium with the growth regulators benzylaminopurine (BAP) and naphthalene acetic acid (NAA) (Taha \& Wafa, 2012; Warhade \& Badere, 2015). However, the concentration of the gelling agents, as well as the supplementation of the culture medium with mineral nutrients, still needs to be better exploited for this species, in order to guarantee a higher development of this ornamental plant.

The in vitro propagation in a solid or semisolid medium may be conducted using gelling agents such as agar, which derives from algae (Gelidium amansii) and is traditionally used in experiments, and alternative substances such as starches and gums (Gordo et al., 2012). However, the type and concentration of these agents in the culture medium may contribute to the occurrence of hyperhydricity, which is a physiological, biochemical, and morphological disorder that results from an abnormal water buildup in the interior of seedling cells and tissues (Vasconcelos et al., 2012).

Plant nutrition is another aspect that needs to be noted in micropopagation since plants must extract all nutrients from the culture medium until they may be maintained under ex vitro condition (García-Gonzáles et al., 2010). Silicon has been recently classified as a beneficial nutrient for plant growth and development (Taiz \& Zeiger, 2013). Therefore, its use has been encouraged in plant tissue cultures due to several benefits for the plant (Sahebi et al., 2016), both in vitro (Dias et al., 2017) and ex vitro (Asmar et al., 2015).

In this context, adding silicon to the culture medium may contribute, for example, to an increase in resistance to low temperatures in the Dendrobium moniliforme orchid (Duan et al., 2013), and to an improvement in the anatomical and physiological characteristics of Anthurium adreaenum, which contributes to ex vitro survival (Dias et al., 2014), among other stimulating factors for plant development.

Although there are reports in the literature about the effects of silicates and gelling agents, singly, as auxiliary substances to the in vitro development of ornamental species - i.e., potassium silicate in sage (Salvia splendens Ker Gawl.) (Soundararajan et al., 2013) and agar in chrysanthemum (Dendranthema $\mathrm{x}$ grandiflora ) (Paiva et al., 1999) - there are no known studies associating this chemical element with agar in ornamental plants, especially of the Celosia genus. Therefore, the differential of this work is based on the exploration of a pure source of silicon, silicic acid, in association with agar, in the in vitro behavior of $C$. cristata.

The objective of this work was to evaluate the effect of silicon and agar concentrations on C. cristata (Amaranthaceae) development in vitro.

\section{Materials and Methods}

For the in vitro culture of $C$. cristata, $400 \mathrm{~mL}$ glass flasks containing $25 \mathrm{~mL}$ of the MS culture medium (Murashige \& Skoog, 1962) plus $30 \mathrm{~g} \mathrm{~L}^{-1}$ of sucrose were used. Silicic acid $\left(\mathrm{SiO}_{2} \cdot \mathrm{XH}_{2} \mathrm{O}\right)$ (Vetec Química Fina Ltda., Duque de Caxias, RJ, Brazil), as well as agar (agar-agar) (Agargel Indústria e Comércio Ltda, João Pessoa, PB, Brazil), were incorporated into the medium, respectively, at the concentrations of $0.0,0.5$, 1.0, and $1.5 \mathrm{~g} \mathrm{~L}^{-1}$ and 5.5, 8.0, and $10.5 \mathrm{~g} \mathrm{~L}^{-1}$. The $\mathrm{pH}$ of the medium was adjusted to 5.8 before autoclaving at $121^{\circ} \mathrm{C}$ and $1.0 \mathrm{~atm}$ for $20 \mathrm{~min}$.

Then, nodal segments of $C$. cristata seedlings established in vitro, with approximately $2 \mathrm{~cm}$ in length, containing two vegetative buds, were inoculated in the flasks in a laminar flow chamber. Afterwards, the flasks were sealed with lids of polypropylene and parafilm plastic, and were kept in a growth room at $25 \pm 2^{\circ} \mathrm{C}$ temperature, $52.5 \mu \mathrm{mol} \mathrm{m}{ }^{-2} \mathrm{~s}^{-1}$ light intensity, and 16 hours of photoperiod.

A completely randomized experimental design was used, in a $4 \times 3$ factorial arrangment (silicic acid concentrations of $0.0,0.5,1.0$, and $1.5 \mathrm{~g} \mathrm{~L}^{-1}$, and agar concentrations of $5.5,8.0$, and $10.5 \mathrm{~g} \mathrm{~L}^{-1}$, totaling 12 treatments and 7 replicates (two nodal segments per flask, and one flask per replicate). Thirty days after inoculation, the following analysis were conducted. 
The phytotechnical analysis consisted of number of leaves, number of shoots, and stem diameter ( $\mathrm{mm}$ ), evaluated in the middle of the plant with the series 799 digital pachymeter (Starrett Itu, SP, Brazil), and shoot lenght $(\mathrm{cm})$, considering the measure from the top to the base of the plant, using a ruler graduated in centimeters, modified by Kanashiro et al. (2007).

For the anatomical analysis, four plants per treatment were used. The foliar samples were fixed on FAA 50 (formaldehyde, acetic acid, and ethyl alcohol $50 \%$, with proportions of 5:5:90, v:v:v), for 48 hours and stored in $70 \%$ ethanol. They were previously dehydrated in an ethanolic series and included in 2-hydroxyethyl-methacrylate (Historesin, Leica Biosystems Nussloch GmbH, Nussloch, Germany). Transverse sections, 5- $\mu \mathrm{m}$ thick, were obtained in the RM2155 rotary microtome (Leica Microsystems Inc., Buffalo Grove, IL, USA), stained with toluidine blue $0.05 \%$, pH 6.5 (O’Brien et al., 1964), and mounted with synthetic resin (Permount, Fisher Scientific, Pittsburgh, PH, USA).

The images were obtained with a digital camera (AxioCam HRc, Carl Zeiss Microscopy GmbH, Jena, Germany) and a microcomputer with an image-capturing software (Axio Vision, Carl Zeiss Microscopy GmbH, Jena, Germany) coupled with a light microscope (AX-70 TRF, Olympus Optical Co., Ltd., Tokyo, Japan). The images were later analyzed using, Image Pro Plus software (Media Cybernetics, Rockville, MD, USA), with the measurement of five fields per replicate, for every variable analyzed. Within each field, five measurements were taken and a mean score was obtained. The width of the leaf blade, the thickness of the palisade and spongy parenchyma, and the thickness of the epidermis of the adaxial and abaxial faces were determined.

The ultrastructural analysis used samples of the middle third of four leaves, which were fixed in Karnovsky (1965) fixative, post-fixed in osmium tetroxide $\left(\mathrm{OsO}_{4}\right)$, and dehydrated in increasing gradients of acetone $(30,50,70,90$, and $100 \%)$. After dehydration, the samples were dried in the CDP 030 critical point dryer, using liquid $\mathrm{CO}_{2}$ (Robards, $1978)$ and then mounted on stubs for gold plating (20 $\mathrm{nm})$. The samples were then analyzed with the LEO Evo 040 electronic scanning microscope (Carl Zeiss Microscopy GmbH, Jena, Germany).
Finaly the data obtained were subjected to a statistical analysis considering the analysis of variance, and the means were compared using the Scott-Knott test, at $5 \%$ probability, with the aid of the Sisvar 4.3 statistical software (Ferreira, 2011).

\section{Results and Discussion}

Regarding the phytotechnical characteristics, there was no significant effect in the interaction between the silicon and agar factors. In addition, the silicic acid concentrations added to the culture mediums did not contribute to the growth of any of the phytotechnical parameters analyzed; on average, 5.51 leaves, 0.80 shoots, $1.22-\mathrm{mm}$ stem diameter, and $3.09-\mathrm{cm}$ shoot length were obtained in seedlings of $C$. cristata in vitro.

The result found in the present research can be explained by the fact that $C$. cristata is a dicotyledonous plant. Plants with this classification are generally considered intermediate in the accumulation of silicon or as nonaccumulators of this element (Ma et al., 2001). This could have contributed to the absence of an response in relation to the phytotechnical parameters. In addition, it is also known that the optimal concentration of silicon that can promote a satisfactory plant development depends on the plant species or genotype (Soares et al., 2013).

Although various researchers have observed increments in phytotechnical parameters through the use of sources containing silicon, such as an increased number of leaves of the orchid, Cattleya loddigesii Lindl., with the incorporation of sodium silicate and potassium in the culture medium (Soares et al., 2011), it is important to stress that these sources are not pure, presenting other elements in their composition, like sodium and potassium. Therefore, the results achieved cannot be attributed exclusively to silicon, but also to other associated elements, as reported by other authors (Soares et al., 2011; Colombo et al., 2016). In contrast, in the present study, a pure source of silicon was used, silicic acid $\left(\mathrm{H}_{4} \mathrm{SiO}_{4}\right)$, which may have been insufficient to ensure a significant result regarding the phytotechnical characteristics, although it has contributed to reduce damage caused by saline stress under in vitro conditions (Rezende et al., 2017). 
However, some studies show that silicate sources did not affect the in vitro development of various plant species, mainly of ornamentals, such as the $C$. loddigesii (Soares et al., 2013) and C. forbesii Lindl. (Colombo et al., 2016) orchids. Thus, the addition of sodium silicate $\left(\mathrm{Na}_{2} \mathrm{SiO}_{3}\right)$ to the Knudson $\mathrm{C}$ culture medium did not affect the growth in the number of orchid shoots (C. loddigesii) (Soares et al., 2013). In addition, the greatest shoot length was obtained in the absence of silicon (Soares et al., 2013), confirming that the using this element does not contribute in a uniform manner to the development of seedlings that are propagated in vitro.

In relation to the gelling agent, the use of $8.0 \mathrm{~g} \mathrm{~L}^{-1}$ agar affected the obtainment of better phytotechnical attributes, such as a greater number of leaves, number of shoots, and shoot length, when compared with the concentrations of 5.5 and $10.5 \mathrm{~g} \mathrm{~L}^{-1}$, which did not differ significantly (Table 1). For stem diameter, the higher contribution was obtained using 5.5 or $8.0 \mathrm{~g} \mathrm{~L}^{-1}$, when compared with the concentration of $10.5 \mathrm{~g} \mathrm{~L}^{-1}$.

Agar, besides being a traditional gelling agent used in researches (Gordo et al., 2012), promotes ideal support conditions for plantlets. The concentration to be used should be carefully defined, because high levels of this substance can affect the availability and dissemination of other components present in the culture medium (Cid, 2010). Another relevant aspect is based on the fact that agar represents one of the most expensive components for the in vitro propagation of plant species on a large scale, especially for ornamental plants (Gallo et al., 2014).

Several studies have been conducted with the goal of finding the optimal concentrations of agar for each plant species. Pasqual et al. (2008) observed

Table 1. Phytotechnical traits of Celosia cristata subjected to different agar concentrations in vitro ${ }^{(1)}$.

\begin{tabular}{lcccc}
\hline $\begin{array}{l}\text { Agar } \\
\text { concentration } \\
\left(\mathrm{g} \mathrm{L}^{-1}\right)\end{array}$ & $\begin{array}{c}\text { Number of } \\
\text { leaves }\end{array}$ & $\begin{array}{c}\text { Number of } \\
\text { shoots }\end{array}$ & $\begin{array}{c}\text { Stem } \\
\text { diameter } \\
(\mathrm{mm})\end{array}$ & $\begin{array}{c}\text { Shoot } \\
\text { length } \\
(\mathrm{cm})\end{array}$ \\
\hline 5.5 & $4.83 \mathrm{~b}$ & $0.70 \mathrm{~b}$ & $1.36 \mathrm{a}$ & $2.86 \mathrm{~b}$ \\
8.0 & $6.42 \mathrm{a}$ & $1.05 \mathrm{a}$ & $1.35 \mathrm{a}$ & $3.63 \mathrm{a}$ \\
10.5 & $5.28 \mathrm{~b}$ & $0.64 \mathrm{~b}$ & $0.94 \mathrm{~b}$ & $2.78 \mathrm{~b}$ \\
\hline $\mathrm{CV}(\%)$ & 42.03 & 85.24 & 34.66 & 43.54 \\
p-value & 0.03 & 0.05 & 0.00 & 0.04 \\
\hline
\end{tabular}

${ }^{(1)}$ Means followed by equal letters do not differ significantly by the ScottKnott test, at $5 \%$ probability. that both the multiplication and in vitro rooting of ornamental pineapple [Ananas comosus (L.) Merr. var. Erectifolius] are favored in liquid MS medium, in the absence of agar, when comparing the concentrations of 2.5, 5.0, and $7.5 \mathrm{~g} \mathrm{~L}^{-1}$. For in vitro propagation of 'Orange Reagen' chrysanthemum, the use of $7 \mathrm{~g} \mathrm{~L}^{-1}$ combined agar with $\mathrm{pH}$ adjusted to 5.8 is recommended, to ensure an adequate consistency of the modified MS medium (Paiva et al., 1999). When evaluating 'Grand Naine' banana (Musa sp.) tree, Costa et al. (2007) found that after three successive subcultures, the highest multiplication rate was obtained with an MS medium gelled solely with agar at a concentration of $6 \mathrm{~g} \mathrm{~L}^{-1}$.

In the present study, the concentration of agar that rendered the best results for the phytotechnical characteristics of $C$. cristata was $8.0 \mathrm{~g} \mathrm{~L}^{-1}$, higher than that normally used for the micropropagation of plant species, like that of $7.0 \mathrm{~g} \mathrm{~L}^{-1}$ for chrysanthemum (Paiva et al., 1999) and of 3.0 or $6.0 \mathrm{~g} \mathrm{~L}^{-1}$ for anise (Pimpinella anisum L.) (Tambosi \& Rogge-Renner, 2010), although concentrations up to $10 \mathrm{~g} \mathrm{~L}^{-1}$ are part of the standards considered suitable for micropropagation, not limiting the diffusion of nutrients to the explant (Pasqual, 2001). Thus, a higher initial spending can contribute to a favorable cost-benefit ratio as a result of obtaining more vigorous and competitive seedlings, which may also contribute to greater longevity and plant quality, which are extremely desirable characteristics in ornamental plants.

Regarding anatomical parameters, there was a significant interaction between the addition of silicon and agar in vitro, contributing to an increase in the width of the leaf blade (Table 2). The use of $10.5 \mathrm{~g} \mathrm{~L}^{-1}$ agar in association with $1.5 \mathrm{~g} \mathrm{~L}^{-1}$ silicon, promoted a mean increase of $643.39 \mu \mathrm{m}$ in the width of the leaf blade in C. cristata plants, in relation to the concentrations of $0.0,0.5$, and $1.0 \mathrm{~g} \mathrm{~L}^{-1}$.

With a concentration of $1.0 \mathrm{~g} \mathrm{~L}^{-1}$ silicon, the greatest development of the leaf blade was detected when agar was also used at lower concentrations (5.5 or $\left.8.0 \mathrm{~g} \mathrm{~L}^{-1}\right)$. The contrary was observed with the use of $1.5 \mathrm{~g} \mathrm{~L}^{-1}$ silicon, where the largest width of the leaf blade $(1,417.17 \mu \mathrm{m})$ was verified with the greatest concentration of agar in vitro $\left(10.5 \mathrm{~g} \mathrm{~L}^{-1}\right)$ (Table 2).

The results obtained in this study corroborate those of Soares et al. (2012), in which the use of 0.5 and $2.0 \mathrm{mg} \mathrm{L}^{-1}$ calcium silicate $\left(\mathrm{CaSiO}_{3}\right)$ for the in vitro cultivation 
of a native orchid (Brassavola perrinii Lindl.) and a hybrid [(Laelia cattleya Culminant 'Tuilerie' x Laelia cattleya Sons Atout Rotunda) x (Brassolaelia cattleya Startifire Moon Beach)], respectively, contributed to the increase in the thickness of the mesophyll of these ornamental plants.

For the palisade parenchyma, no significant difference was observed between concentrations of silicon with the use of $5.5 \mathrm{~g} \mathrm{~L}^{-1}$ agar. However, the use of $8.0 \mathrm{~g} \mathrm{~L}^{-1}$ agar associated with $1.0 \mathrm{~g} \mathrm{~L}^{-1}$ silicon or of $10.5 \mathrm{~g} \mathrm{~L}^{-1}$ agar in the presence of $1.5 \mathrm{~g} \mathrm{~L}^{-1}$ silicon was favorable for a thicker plant tissue. Comparing the concentrations of agar with the presence of $1.0 \mathrm{~g} \mathrm{~L}^{-1}$ of silicon, verified that the use of 5.5 or $8.0 \mathrm{~g} \mathrm{~L}^{-1}$ of the solidifying agent promoted a mean increase in the thickness of the palisade parenchyma of $110.09 \mu \mathrm{m}$ in relation to the use of $10.5 \mathrm{~g} \mathrm{~L}^{-1}$ agar (Table 2).

Significant differences were not found between silicon concentrations with the use of 5.5 or $8.0 \mathrm{~g} \mathrm{~L}^{-1}$ agar in the thickness of the spongy parenchyma of the plants. However, the addition of silicon $\left(1.5 \mathrm{~g} \mathrm{~L}^{-1}\right)$ had positive effects on $C$. cristata with a greater

Table 2. Anatomical traits of Celosia cristata subjected to different concentrations of silicon and agar in vitro.

\begin{tabular}{|c|c|c|c|}
\hline \multirow{2}{*}{$\begin{array}{l}\text { Silicon concen- } \\
\text { tration }\left(\mathrm{g} \mathrm{L}^{-1}\right)\end{array}$} & \multicolumn{3}{|c|}{ Agar concentration } \\
\hline & $5.5 \mathrm{~g} \mathrm{~L}^{-1}$ & $8.0 \mathrm{~g} \mathrm{~L}^{-1}$ & $10.5 \mathrm{~g} \mathrm{~L}^{-1}$ \\
\hline & \multicolumn{3}{|c|}{ Leaf blade width $(\mu \mathrm{m})$} \\
\hline 0 & $978.57 \mathrm{aA}$ & $861.46 \mathrm{aA}$ & $695.34 \mathrm{bA}$ \\
\hline 0.5 & $827.77 \mathrm{aA}$ & $1050.53 \mathrm{aA}$ & $821.42 \mathrm{bA}$ \\
\hline 1.0 & $1162.58 \mathrm{aA}$ & $1141.74 \mathrm{aA}$ & $804.57 \mathrm{bB}$ \\
\hline 1.5 & $1079.16 \mathrm{aB}$ & $920.70 \mathrm{aB}$ & $1417.17 \mathrm{aA}$ \\
\hline$\overline{C V}(\%)$ & & 15.80 & \\
\hline \multirow[t]{2}{*}{ p-value } & & $<0.01$ & \\
\hline & \multicolumn{3}{|c|}{ Palisade parenchyma length $(\mu \mathrm{m})$} \\
\hline 0 & $207.12 \mathrm{aA}$ & $190.58 \mathrm{bA}$ & $151.95 \mathrm{bA}$ \\
\hline 0.5 & $156.78 \mathrm{aA}$ & $198.81 \mathrm{bA}$ & $164.35 \mathrm{bA}$ \\
\hline 1.0 & $261.37 \mathrm{aA}$ & $267.22 \mathrm{aA}$ & $154.20 \mathrm{bB}$ \\
\hline 1.5 & $202.49 \mathrm{aA}$ & $200.37 \mathrm{bA}$ & $262.92 \mathrm{aA}$ \\
\hline$\overline{C V}(\%)$ & & 19.31 & \\
\hline \multirow[t]{2}{*}{ p-value } & & $<0.01$ & \\
\hline & \multicolumn{3}{|c|}{ Spongy parenchyma length $(\mu \mathrm{m})$} \\
\hline 0 & $578.77 \mathrm{aA}$ & $520.02 \mathrm{aA}$ & $397.21 \mathrm{bA}$ \\
\hline 0.5 & $509.72 \mathrm{aA}$ & $685.10 \mathrm{aA}$ & $495.71 \mathrm{bA}$ \\
\hline 1.0 & $731.41 \mathrm{aA}$ & $692.26 \mathrm{aA}$ & $503.72 \mathrm{bA}$ \\
\hline 1.5 & $708.75 \mathrm{aB}$ & $539.27 \mathrm{aB}$ & $960.13 \mathrm{aA}$ \\
\hline CV (\%) & & 21.40 & \\
\hline p-value & & $<0.01$ & \\
\hline
\end{tabular}

(1)Means followed by equal letters, lower case in the columns and upper case in the lines, do not differ significantly by the Scott-Knott test, at 5\% probability. concentration of agar $\left(10.5 \mathrm{~g} \mathrm{~L}^{-1}\right)$, promoting an average increment of $494.59 \mu \mathrm{m}$ in relation to its absence, with 0.5 and $1.0 \mathrm{~g} \mathrm{~L}^{-1}$ silicon (Table 2). Regarding the addition of agar within each silicon concentration, a thicker spongy parenchyma was observed with the use of $10.5 \mathrm{~g} \mathrm{~L}^{-1}$ agar when compared with 5.5 and $8.0 \mathrm{~g} \mathrm{~L}^{-1}$, associated with the presence of $1.5 \mathrm{~g} \mathrm{~L}^{-1}$ silicon.

The results found in relation to the thickness of the sponge parenchyma resemble those of Braga et al. (2009), in which the use of sources of silicon in vitro, such as potassium or calcium silicate and sodium silicate, favored the increase in the thickness of these tissues in strawberry (Fragaria $\mathrm{x}$ ananassa) seedlings obtained through micropropagation.

The main practical contribution of this result is based on the fact that plants with thicker leaf tissues likely have a higher chance of survival during transfer to an ex vitro environment, becoming less subject to stresses resulting from a shifting of cultivation environment (Asmar et al., 2015). Therefore, it has already been observed that in vitro-induced anatomical changes, through the incorporation of silicon into the culture medium, can be expressed in ex vitro conditions, favoring acclimatization, which is the final phase of the micropropagation process of the plants (Asmar et al., 2015).

Furthermore, since the palisade parenchyma is the primary tissue related to photosynthesis, because it is rich in chloroplasts, a greater thickness might contribute to greater efficiency in the biological process (Castro et al., 2009), favoring the plants that were cultured in vitro with silicon. Although this physiological parameter was not investigated in this research, observations made by Dias et al. (2017) in anthurium (Anthurium andraeanum 'Rubi'), allow to infer that there is a tendency of increase in the levels of chlorophyll a, b, and total, as the sodium silicate concentration increases in the Pierik culture medium, and the best result is that obtained with the concentration of $2 \mathrm{mg} \mathrm{L}^{-1}$. In addition, the greater thickness may offer greater tolerance to the plants when exposed to high solar radiation, allowing the rearrangement of the chloroplasts to avoid light excess (Taiz \& Zeiger, 2013) in ex vitro conditions.

A thicker spongy parenchyma can facilitate a greater accumulation of gases for gas exchange, because this tissue is abundant in intercellular space, due to the 
irregular shape of the cells that make it up (Castro et al., 2009).

In contrast, there was no significant effect involving the concentration factors of silicon and agar in vitro on the thickness of the adaxial and abaxial epidermal faces of the $C$. cristata plants; the mean values obtained were 83.29 and $74.16 \mu \mathrm{m}$, respectively (Figures 1 and 2).

Based on Illoh (1995), the adaxial surface of $C$. cristata can be defined as being flat in the proximal region, slightly raised in the middle region and convex in the distal region. On the abaxial surface, it appears as a generally round portion in the three regions.

Overlying the upper surface of the sheet of cells, the adaxial epidermis, compared with the abaxial epidermis, is more prone to adverse environmental factors such as solar radiation and high temperatures, which may change the morphology of the tissue.

However, according to Dias et al. (2014), an elevation in the concentration of silicon in vitro was responsible for a reduction in the thickness of the adaxial and abaxial epidermis of anthurium, and the best results were achieved in the absence of sodium silicate.

The foliar sipes of $C$. cristata were subjected to different concentrations of silicon and agar in vitro (Figures 1 and 2). It was observed that the palisade parenchyma tissue is uniseriate. However, the treatments with $1.0 \mathrm{~g} \mathrm{~L}^{-1}$ silicic acid and $10.5 \mathrm{~g}$ $\mathrm{L}^{-1}$ agar and $1.5 \mathrm{~g} \mathrm{~L}^{-1}$ silicic acid and $10.5 \mathrm{~g} \mathrm{~L}^{-1}$ agar decreased the cell length of this tissue, and a second layer was added. This behavior may be due to the high concentration of silicon and agar. The addition of this layer contributes to a better utilization of sunlight, in ex vitro conditions, since there is a larger area for interception (Valladares et al., 2012). Thus, these concentrations of silicon possibly contribute to an increase in the photosynthetic potential of plants grown with said concentrations, as already reported by Dias et al. $(2014,2017)$ in anthurium.

It was also observed that the size of the cells was greater in the treatments with the highest silicon and agar combined (Figure $1 \mathrm{C}$ and D and Figure $2 \mathrm{~A}, \mathrm{~B}$, $\mathrm{E}$, and F), but smaller in most of the treatments with low concentrations of silicon associated with agar (Figure 1 A, B, E, and F and Figure $2 \mathrm{C}$ and D). The presence of calcium crystals was noted inside the cells of the spongy parenchyma (Figure $1 \mathrm{~A}, \mathrm{~B}$, and F and Figure $2 \mathrm{~A}$ ).
The presence of stomata was observed in the two epidermis (Figures 1 and 2), always identified by their vast stomatal subchambers. It can also be observed that the locations of the stomata in relation to the vascular bundles is strategic, which is mainly shown in Figure 2 A and D. In all of the treatments, the proximity of the stomata and vascular bundles increased the efficiency of the translocation of the photosynthetic products to the rest of the plant (Taiz \& Zeiger, 2013). Anomocytic and anisocytic stomata with oval guard cells were observed (Figure 3 B, D, and E and Figure 4 A, B, D, $\mathrm{E}$, and $\mathrm{F}$ ), and the stomata are present on both faces of the epidermis, but more frequently on the abaxial face (Figures 1 and 2).

The presence of stomata in this research was rare, due to the silicon and agar concentrations used, although it was detected by scanning microscopy images in the two epidermis, which made more detailed analyzes impossible. Soares et al. (2012) observed a restriction caused by calcium silicate in vitro in the stomata of the native orchid $B$. perrinii due to a reduction in stomatal density and functionality, as a result of the relation between the polar and equatorial diameters, indicating that the stomata of this species without the added silicon can be more efficient to capture $\mathrm{CO}_{2}$ and prevent water loss.

When describing the leaf surface of $C$. cristata using scanning electron micrographs, silicon deposition was not observed, despite different concentrations of silicic acid in vitro having been tested. However, stomata and glandular trichomes were sparsely distributed along the foliar surface of the ornamental plant (Figures 3 and 4), indicating a possible adaptive strategy of plants in vitro.

The absence of silicon deposition can be explained by the low age of the seedlings. The accumulation of silicon is affected by transpiration rates, since older leaves have significantly more silicon than younger ones, mainly due to the translocation of silicon by the transpiration flow (Piperno, 2006). Furthermore, considering deposited silicon is not remobilized (Hartley et al., 2015), foliar silicon levels increase both with plant and leaf age (Reynolds et al., 2012).

The presence of glandular trichomes was observed (Figure $3 \mathrm{~A}, \mathrm{C}$, and $\mathrm{F}$ and Figure $4 \mathrm{C}$ and $\mathrm{E})$, consisting of more than one cell, classified as long-stalked glands with thin-walled heads (Guimarães et al., 1999). Although Illoh (1995) has described trichomes as uniseriate, in this species, 
in general, the trichomes are more numerous in the abaxial surface. In strawberry, an incorporation of silicates into the culture medium of MS favored the incidence of glandular trichomes (Braga et al.,
2009), as well as of the tectores (Calvete et al., 2002) that are usually found in in vitro studies of this fruit. According to Illoh (1995), the epidermal cells of $C$. cristata leaves are polygonal on the adaxial surface, which has straight to curved walls, and are rectangular
A

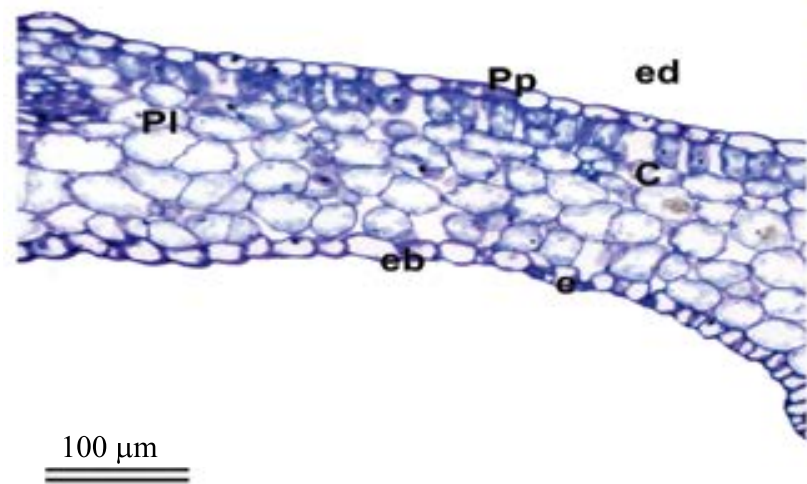

C

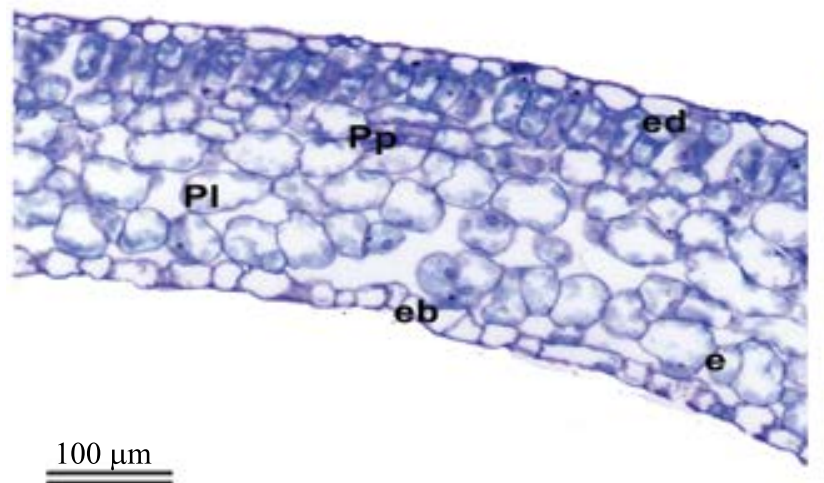

E

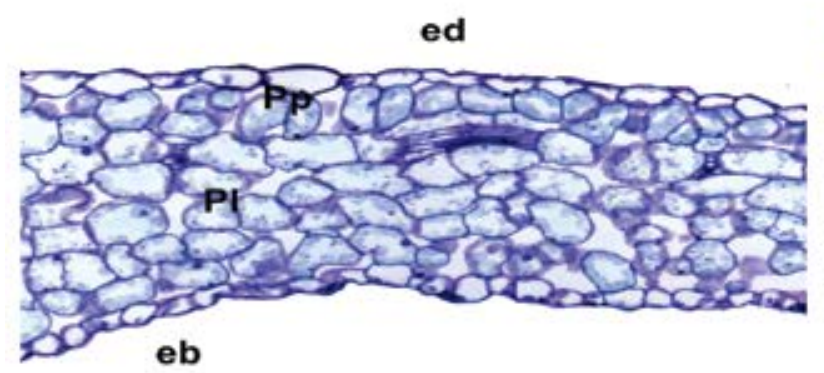

B

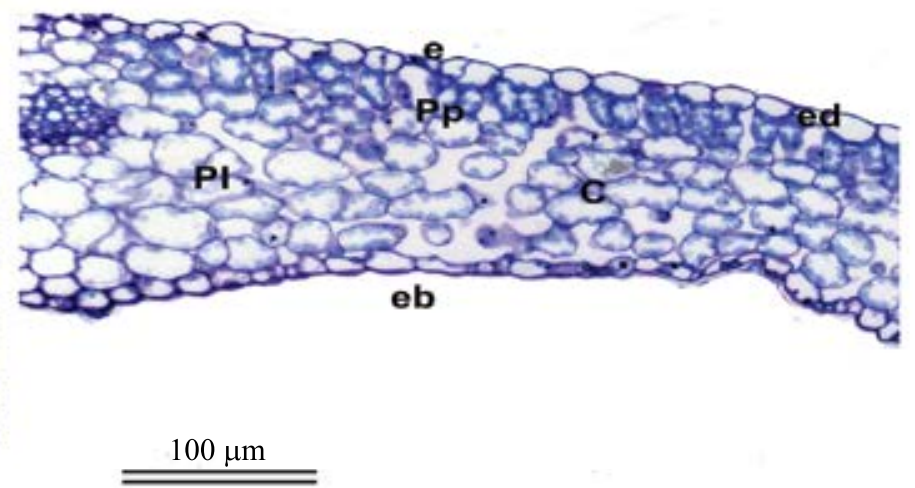

D

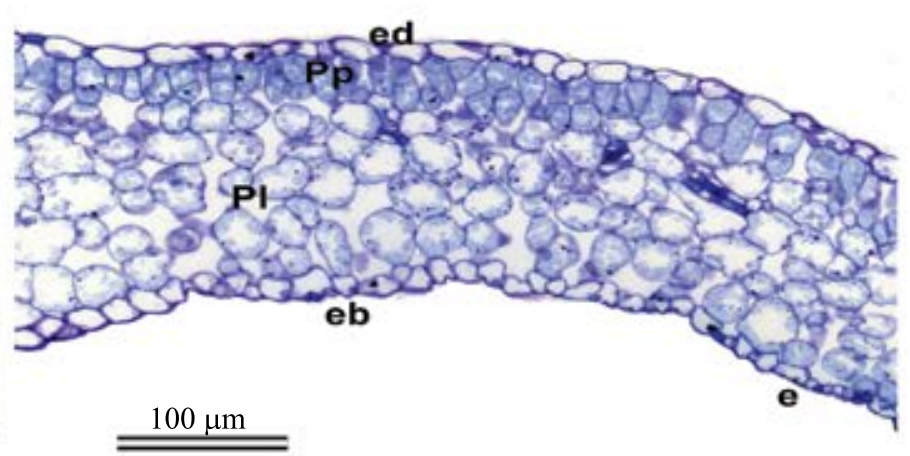

$\mathrm{F}$

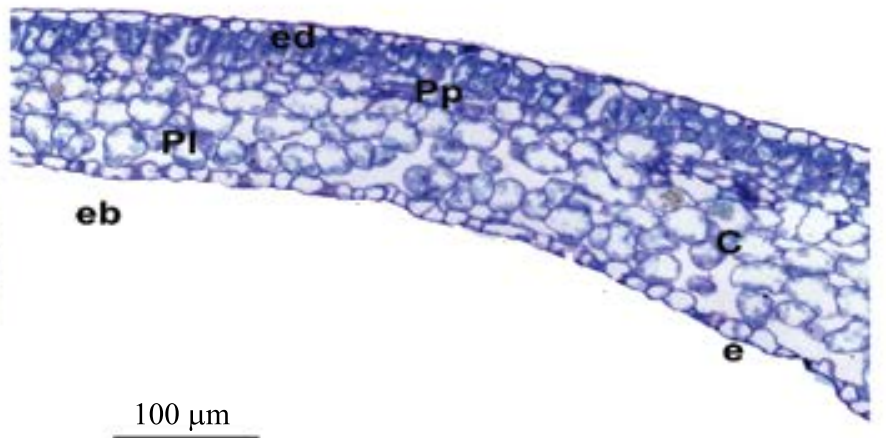

Figure 1. Transverse section of Celosia cristata leaf stained with toluidine blue: $\mathrm{A}, 0.0 \mathrm{~g} \mathrm{~L}^{-1}$ silicic acid $+5.5 \mathrm{~g} \mathrm{~L}^{-1}$ agar; $\mathrm{B}$, $0.5 \mathrm{~g} \mathrm{~L}^{-1}$ silicic acid $+5.5 \mathrm{~g} \mathrm{~L}^{-1}$ agar; $\mathrm{C}, 1.0 \mathrm{~g} \mathrm{~L}^{-1}$ silicic acid $+5.5 \mathrm{~g} \mathrm{~L}^{-1}$ agar; $\mathrm{D}, 1.5 \mathrm{~g} \mathrm{~L}^{-1}$ silicic acid $+5.5 \mathrm{~g} \mathrm{~L}^{-1}$ agar; $\mathrm{E}, 0.0 \mathrm{~g}$ $\mathrm{L}^{-1}$ silicic acid $+8.0 \mathrm{~g} \mathrm{~L}^{-1}$ agar; and $\mathrm{F}, 0.5 \mathrm{~g} \mathrm{~L}^{-1}$ silicic acid $+8.0 \mathrm{~g} \mathrm{~L}^{-1}$ agar. The bars represent $100 \mu \mathrm{m}$. Ed, adaxial epidermis; $\mathrm{Eb}$, abaxial epidermis; Pp, palisade parenchyma; Pl, spongy parenchyma; e, stomata; and c, calcium crystal. 
to polygonal on the abaxial surface. Similar results were observed in the present study, by light and scanning microscopy images (Figures 3 and 4).

In light of the above, silicon can be considered a beneficial macronutrient by improving the structural integrity and strengthening the plant cell walls (Taiz \& Zeiger, 2013). The optimal concentration to be used should be considered in its addition to the culture medium for the improvement of the anatomical attributes of $C$. cristata. Moreover, it is important to
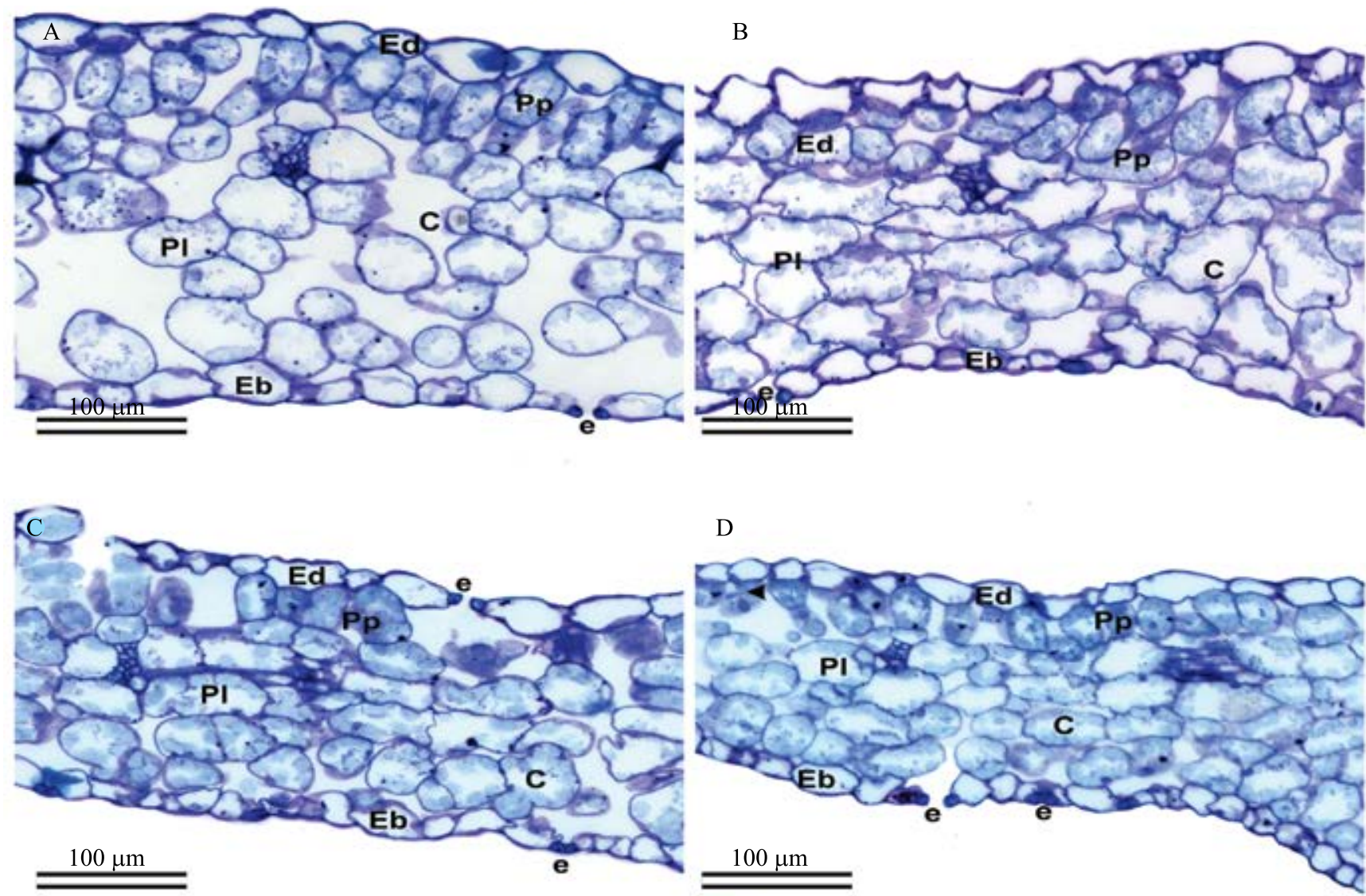

D

$\mathrm{E}$
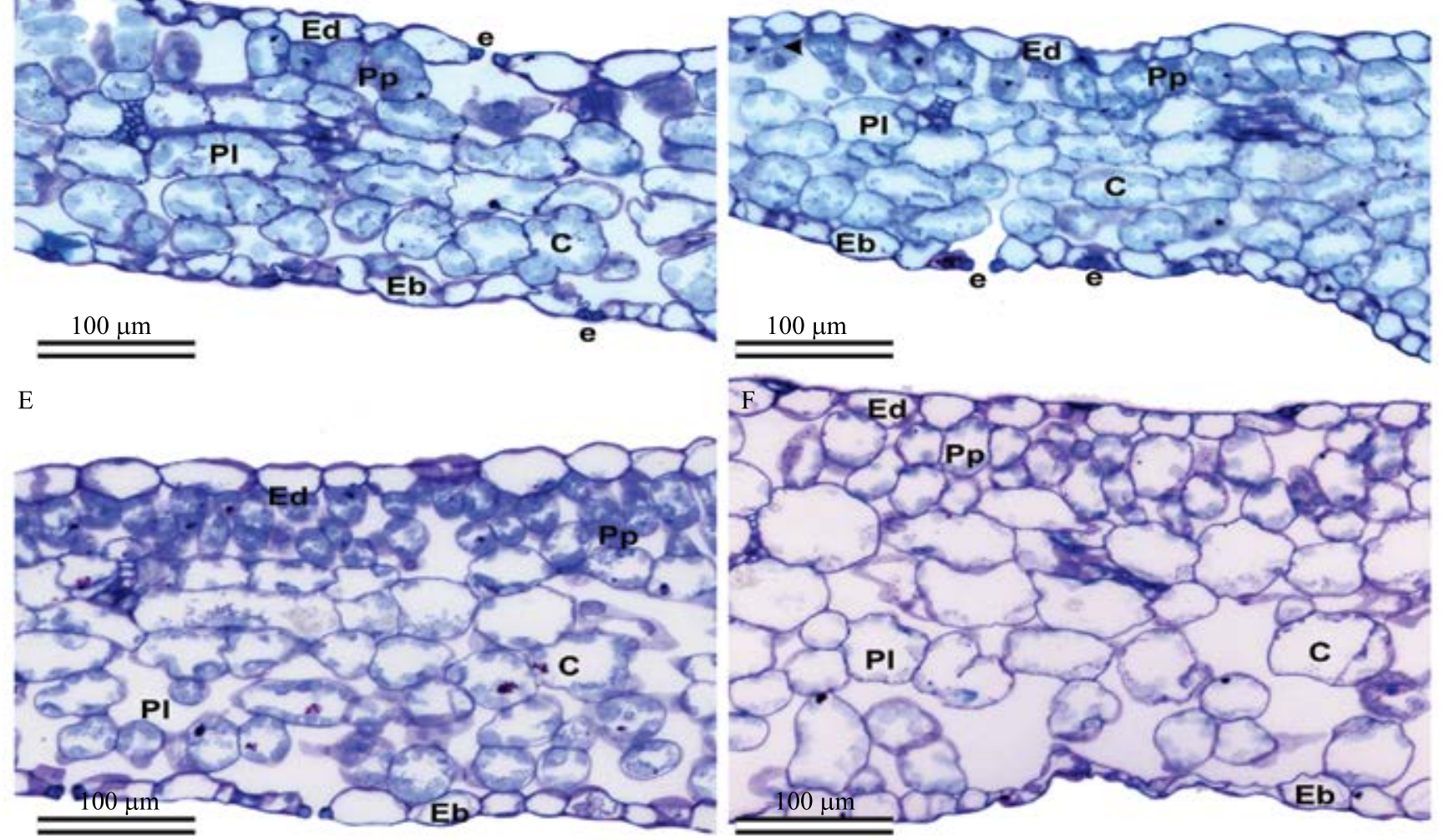

Figure 2. Transverse section of Celosia cristata leaf stained with toluidine blue: $\mathrm{A}, 1.0 \mathrm{~g} \mathrm{~L}^{-1}$ silicic acid $+8.0 \mathrm{~g} \mathrm{~L}-1$ agar; $\mathrm{B}$, $1.5 \mathrm{~g} \mathrm{~L}^{-1}$ silicic acid $+8.0 \mathrm{~g} \mathrm{~L}^{-1}$ agar; C, $0.0 \mathrm{~g} \mathrm{~L}^{-1}$ silicic acid $+10.5 \mathrm{~g} \mathrm{~L}^{-1}$ agar; $\mathrm{D}, 0.5 \mathrm{~g} \mathrm{~L}^{-1}$ silicic acid $+10.5 \mathrm{~g} \mathrm{~L}^{-1}$ agar; E, $1.0 \mathrm{~g} \mathrm{~L}^{-1}$ silicic acid $+10.5 \mathrm{~g} \mathrm{~L}^{-1}$ agar; and F, $1.5 \mathrm{~g} \mathrm{~L}^{-1}$ silicic acid $+10.5 \mathrm{~g} \mathrm{~L}^{-1}$ agar. The bars represent $100 \mu \mathrm{m}$. Ed, adaxial epidermis; Eb, abaxial epidermis; Pp, palisade parenchyma; Pl, spongy parenchyma; e, stomata; and c, calcium crystal. 
note that the concentration of agar to be used, besides showing critical importance in supporting plantlets, also contributes as much to the development in vitro as to the anatomy of the plants, playing an important role in obtaining seedlings with greater prospects of survival and longevity ex vitro.
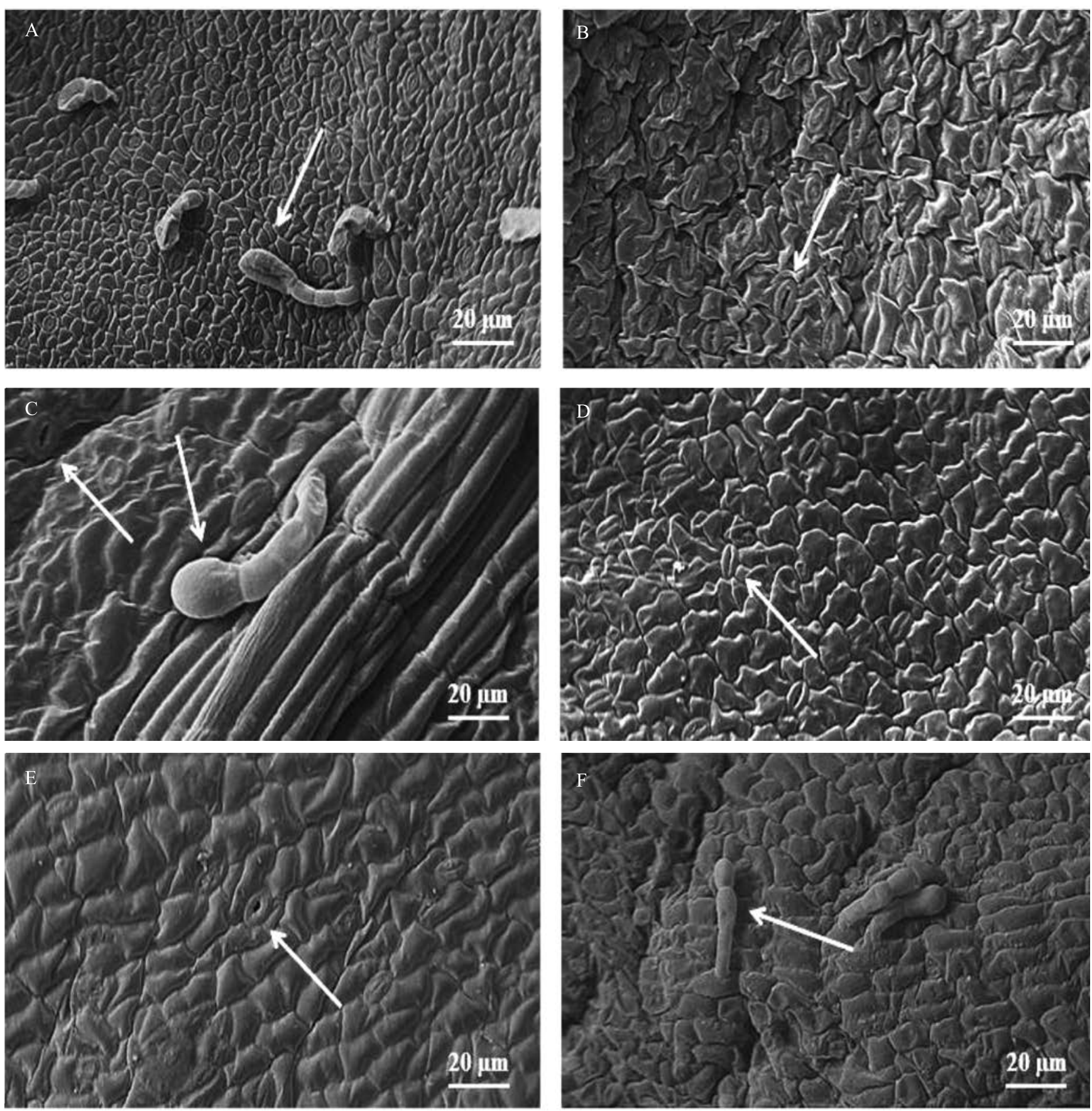

Figure 3. Scanning electronic micrographs of the epidermis appearance in Celosia cristata leaves subjected to different concentrations of silicon and agar in vitro: A, $0.0 \mathrm{~g} \mathrm{~L}^{-1}$ silicic acid $+5.5 \mathrm{~g} \mathrm{~L}^{-1}$ agar; $\mathrm{B}, 0.5 \mathrm{~g} \mathrm{~L}^{-1}$ silicic acid $+5.5 \mathrm{~g} \mathrm{~L}^{-1}$ agar; C, $1.0 \mathrm{~g} \mathrm{~L}^{-1}$ silicic acid $+5.5 \mathrm{~g} \mathrm{~L}^{-1}$ agar; D, $1.5 \mathrm{~g} \mathrm{~L}^{-1}$ silicic acid $+5.5 \mathrm{~g} \mathrm{~L}^{-1}$ agar; E, $0.0 \mathrm{~g} \mathrm{~L}^{-1}$ silicic acid $+8.0 \mathrm{~g} \mathrm{~L}^{-1}$ agar; and F, 0.5 $\mathrm{g} \mathrm{L}^{-1}$ silicic acid $+8.0 \mathrm{~g} \mathrm{~L}^{-1}$ agar. The bars represent $20 \mu \mathrm{m}$. Arrows indicate the presence of stomata and glandular trichomes.

Pesq. agropec. bras., Brasília, v.53, n.1, p.30-41, Jan. 2018

DOI: 10.1590/S0100-204X2018000100004 

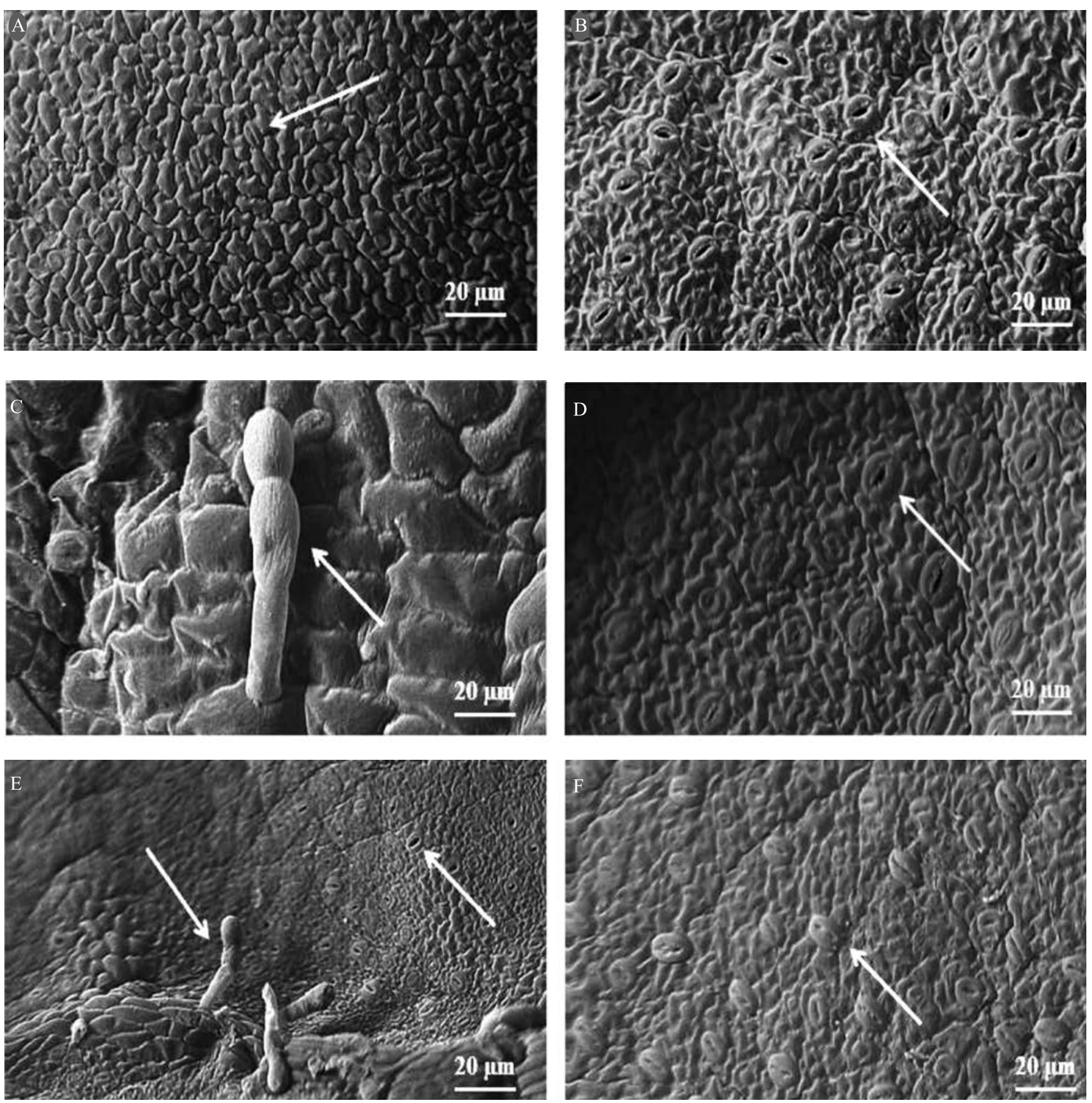

Figure 4. Scanning electronic micrographs of the epidermis appearance in Celosia cristata leaves subjected to different concentrations of silicon and agar in vitro: $\mathrm{A}, 1.0 \mathrm{~g} \mathrm{~L}^{-1}$ silicic acid $+8.0 \mathrm{~g} \mathrm{~L}^{-1}$ agar; $\mathrm{B}, 1.5 \mathrm{~g} \mathrm{~L}^{-1}$ silicic acid $+8.0 \mathrm{~g} \mathrm{~L}^{-1}$ agar; $\mathrm{C}, 0.0$ $\mathrm{g} \mathrm{L}^{-1}$ silicic acid $+10.5 \mathrm{~g} \mathrm{~L}^{-1}$ agar; D, $0.5 \mathrm{~g} \mathrm{~L}^{-1}$ silicic acid $+10.5 \mathrm{~g} \mathrm{~L}^{-1}$ agar; E, $1.0 \mathrm{~g} \mathrm{~L}^{-1}$ silicic acid $+10.5 \mathrm{~g} \mathrm{~L}^{-1}$ agar; and F, 1.5 $\mathrm{g} \mathrm{L}^{-1}$ silicic acid $+10.5 \mathrm{~g} \mathrm{~L}^{-1}$ agar. The bars represent $20 \mu \mathrm{m}$. Arrows indicate the presence of stomata and glandular trichomes.

\section{Conclusions}

1. Agar improves the phytotechnical characteristics of Celosia cristata at the concentration of $8.0 \mathrm{~g} \mathrm{~L}^{-1}$, contributing to its development in vitro.
2. The combination of silicon and agar at the concentrations of 1.0 and $8.0 \mathrm{~g} \mathrm{~L} \mathrm{~L}^{-1}$, respectively, improve C. cristata anatomical attributes, such as leaf blade width and thickness of the palisade and spongy parenchyma. 
3. None of the evaluated combinations of silicon and agar contribute to the deposition of $\mathrm{Si}$ in the foliar epidermis of C. cristata.

\section{Acknowledgments}

To Conselho Nacional de Desenvolvimento Científico e Tecnológico $(\mathrm{CNPq}$, process No. 500828/2014-8), for scholarship granted.

\section{References}

ASMAR, S.A.; SOARES, J.D.R.; SILVA, R.A.L.; PASQUAL, M.; PIO, L.A.S.; CASTRO, E.M. de. Anatomical and structural changes in response to application of silicon ( $\mathrm{Si}$ ) in vitro during the acclimatization of banana cv. 'Grand Naine'. Australian Journal of Crop Science, v.9, p.1236-1241, 2015.

BODHIPADMA, K.; NOICHINDA, S.; YADBUNTUNG, I.; BUAEIAM, W.; LEUNG, D.W.M. Comparison of in vitro and in vivo inflorescence of common cockscomb (Celosia argentea var. cristata). Science Asia, v.36, p.68-71, 2010. DOI: 10.2306/ scienceasia1513-1874.2010.36.068.

BRAGA, F.T.; NUNES, C.F.; FAVERO, A.C.; PASQUAL, M.; CARVALHO, J.G. de; CASTRO, E.M. de. Características anatômicas de mudas de morangueiro micropropagadas com diferentes fontes de silício. Pesquisa Agropecuária Brasileira, v.44, p.128-132, 2009. DOI: 10.1590/S0100-204X2009000200003.

CALVETE, E.O.; AZEVEDO, M.; BORDIGNON, M.H.; SUZIN, M. Análises anatômicas e da biomassa em plantas de morangueiro cultivadas in vitro e ex vitro. Horticultura Brasileira, v.20, p.649-653, 2002. DOI: 10.1590/S0102-05362002000400028.

CASTRO, E.M. de; PEREIRA, F.J.; PAIVA, R. Histologia vegetal: estrutura e função de órgãos vegetativos. Lavras: Ed. da UFLA, 2009. 234p.

CID, L.P.B. (Ed.). Cultivo in vitro de plantas. Brasília: Embrapa Informação Tecnológica, 2010. 303p.

COLOMBO, R.C.; FAVETTA, V.; FARIA, R.T. de; ANDRADE, F.A. de; MELEM, V.M. Response of Cattleya forbesii orchid to increasing silicon concentrations in vitro. Revista Caatinga, v.29, p.18-24, 2016. DOI: 10.1590/1983-21252016v29n103rc.

COSTA, F.H. da S.; PEREIRA, M.A.A.; OLIVEIRA, J.P. de; PEREIRA, J.E.S. Efeito de agentes geleificantes alternativos no meio de cultura no cultivo in vitro de abacaxizeiro e bananeira. Ciência e Agrotecnologia, v.31, p.41-46, 2007. DOI: 10.1590/ S1413-70542007000100006.

DAUD, N.; TAHA, R.M.; NOOR, N.N.M.; ALIMON, H. Provision of low cost media options for in vitro culture of Celosia sp. African Journal of Biotechnology, v.10, p.18349-18355, 2011. DOI: 10.5897/AJB11.2234.

DIAS, G. de M.G.; SOARES, J.D.R.; PASQUAL, M.; SILVA, R.A.L.; RODRIGUES, L.C. de A.; PEREIRA, F.J.; CASTRO, E.M. de. Photosynthesis and leaf anatomy of Anthurium cv. Rubi plantlets cultured in vitro under different silicon (Si) concentrations. Australian Journal of Crop Science, v.8, p.1160-1167, 2014.

DIAS, G. de M.G.; SOARES, J.D.R.; RIBEIRO, S.F.; MARTINS, A.D.; PASQUAL, M.; ALVES, E. Morphological and physiological characteristics in vitro anthurium plantlets exposed to silicon. Crop Breeding and Applied Biotechnology, v.17, p.18-24, 2017. DOI: 10.1590/1984-70332017v17n1a3.

DUAN, X.; TANG, M.; WANG, W. Effects of silicon on physiology and biochemistry of Dendrobium moniliforme plantlets under cold stress. Agricultural Biotechnology, v.2, p.18-21, 2013.

FERREIRA, D.F. SISVAR: a computer statistical analysis system. Ciência e Agrotecnologia, v.35, p.1039-1042, 2011. DOI: 10.1590/S1413-70542011000600001.

FERREIRA, E.G.B. de S.; MATOS, V.P.; SENA, L.H. de M.; SALES, A.G. de F.A.; SANTOS, H.H.D. Superação da dormência em sementes de crista de galo. Ciência Rural, v.42, p.808-813, 2012. DOI: $10.1590 / \mathrm{S} 0103-84782012000500008$.

GALLO, F.R.; KUHN, B.C.; MILANEZE-GUTIERRE, M.A. Cultivo in vitro de Cattleya loddigesii (Orchidaceae) sobre suportes alternativos ao ágar. SaBios: Revista de Saúde e Biologia, v.9, p.17-22, 2014.

GARCÍA-GONZÁlES, R.; QUIROZ, K.; CARRASCO, B.; CALIGARI, P. Plant tissue culture: current status, opportunities and challenges. Ciencia e Investigación Agraria, v.37, p.5-30, 2010. DOI: $10.4067 /$ S0718-16202010000300001.

GONÇALVES, K.G.; PASA, M.C. A etnobotânica e as plantas medicinais na Comunidade Sucuri, Cuiabá, MT, Brasil. Interações, v.16, p.245-256, 2015. DOI: 10.1590/151870122015201.

GORDO, D.A.M.; GONZALEZ, O.C.; PACHECO, J.C. Sustancias utilizadas como agente gelificante alternativas al agar en medios de cultivo para propagación in vitro. Revista de Investigación Agraria y Ambiental, v.3, p.49-62, 2012. DOI: 10.22490/21456453.972.

GUIMARÃES, P.J.F.; RANGA N.T.; MARTINS, A.B. Morfologia dos tricomas em Tibouchina sect. Pleroma (D. Don) cogn. (melastomataceae). Brazilian Archives of Biology and Technology, v.42, 1999. DOI: 10.1590/S151689131999000400015.

HARTLEY, S.E.; FITT, R.N.; MCLARNON, E.L.; WADE, R.N. Defending the leaf surface: intra-and inter-specific differences in silicon deposition in grasses in response to damage and silicon supply. Frontiers in Plant Science, v.6, p.1-8, 2015. Article 35. DOI: 10.3389/fpls.2015.00035.

ILLOH, H.C. Foliar epidermis and petiole anatomy of four species of Celosia L. in Nigeria. Feddes Repertorium, v.106, p.15-23, 1995. DOI: 10.1002/fedr.19951060107.

KANASHIRO, S.; RIBEIRO, R. de C.S.; GONÇALVES, A.N.; DIAS, C.T. dos S.; JOCYS, T. Efeitos de diferentes concentrações de nitrogênio no crescimento de Aechmea blanchetiana (Baker) L.B. Sm. cultivada in vitro. Hoehnea, v.34, p.59-66, 2007. DOI: 10.1590/S2236-89062007000100003. 
KARNOVSKY, M.J. A formaldehyde-glutaraldehyde fixative of high osmolality for use in electron microscopy. Journal of Cell Biology, v.27, p.1A-149A, 1965.

MA, J.F.; MIYAKE, Y.; TAKAHASHI, E. Silicon as a beneficial element for crop plants. In: DATNOFF, L.E.; SNYDER, G.H.; KORNDÖRFER, G.H. (Ed.). Silicon in agriculture. Amsterdam: Elsevier, 2001. p.17-39. (Studies in Plant Science, 8). DOI: $10.1016 / \mathrm{S} 0928-3420(01) 80006-9$.

MURASHIGE, T.; SKOOG, F. A revised medium for rapid growth and bio assays with tobacco tissue cultures. Physiologia Plantarum, v.15, p.473-497, 1962. DOI: 10.1111/j.13993054.1962.tb08052.x.

O'BRIEN, T.P.; FEDER, N.; MCCULLY, M.E. Polychromatic staining of plant cell walls by toluidine blue O. Protoplasma, v.59, p.368-373, 1964. DOI: 10.1007/BF01248568.

PAIVA, P.D. de O.; PASQUAL, M.; PAIVA, R. Efeito de concentrações de ágar e níveis de $\mathrm{pH}$ na propagação in vitro de crisântemo. Revista Ceres, v.46, p.141-148, 1999.

PASQUAL, M. Meios de cultura. Lavras: UFLA/FAEPE, 2001. $74 \mathrm{p}$.

PASQUAL, M.; SANTOS, F.C.; FIGUEIREDO, M.A. de; JUNQUEIRA, K.P.; REZENDE, J.C. de; FERREIRA, E.A. Micropropagação do abacaxizeiro ornamental. Horticultura Brasileira, v.26, p.45-49, 2008. DOI: 10.1590/S010205362008000100009.

PIPERNO, D.R. Phytoliths: a comprehensive guide for Archaeologists and Paleoecologists. Lanham: Altamira, 2006. 238p.

REYNOLDS, J.J.H.; LAMBIN, X.; MASSEY, F.P.; REIDINGER, S.; SHERRATT, J.A.; SMITH, M.J.; WHITE, A.; HARTLEY, S.E. Delayed induced silica defences in grasses and their potential for destabilising herbivore population dynamics. Oecologia, v.170, p.445-456, 2012. DOI: 10.1007/s00442-012-2326-8.

REZENDE, R.A.L.S.; SOARES, J.D.R.; SANTOS, H.O. dos; PASQUAL, M.; BRAGA JUNIOR, R.A.; REIS, R.O.; RODRIGUES, F.A.; RAMOS, J.D. Effects of silicon on antioxidant enzymes, $\mathrm{CO}_{2}$, proline and biological activity of in vitro-grown cape gooseberry under salinity stress. Australian Journal of Crop Science, v.11, p.438-446, 2017. DOI: 10.21475/ ajes.17.11.04.335.

ROBARDS, A.W. An introduction to techniques for scanning electron microscopy of plant cells. In: HALL, J.L. (Ed.). Electron microscopy and cytochemistry of plant cells. Amsterdam: Elsevier, 1978. p.343-444.

SAHEBI, M.; HANAFI, M.M.; AZIZI, P. Application of silicon in plant tissue culture. In Vitro Cellular and Developmental Biology - Plant, v.52, p.226-232, 2016. DOI: 10.1007/s11627-0169757-6.
SOARES, J.D.R.; PASQUAL, M.; ARAUJO, A.G. de; CASTRO, E.M. de; PEREIRA, F.J.; BRAGA, F.T. Leaf anatomy of orchids micropropagated with different silicon concentrations. Acta Scientiarum. Agronomy, v.34, p.413-421, 2012. DOI: 10.4025/ actasciagron.v34i4.15062.

SOARES, J.D.R.; PASQUAL, M.; RODRIGUES, F.A.; VILLA, F.; ARAÚJO, A.G. de. Fontes de silício na micropropagação de orquídea do grupo Cattleya. Acta Scientiarum. Agronomy, v.33, p.503-507, 2011. DOI: 10.4025/actasciagron.v33i3.6281.

SOARES, J.D.R.; VILLA, F.; RODRIGUES, F.A.; PASQUAL, M. Concentrações de silício e $\mathrm{GA}_{3}$ na propagação in vitro de orquídea em condição de luz natural. Scientia Agraria Paranaensis, v.12, p.286-292, 2013. DOI: 10.18188/1983-1471/ sap.v12n4p286-292.

SOUNDARARAJAN, P.; SIVANESAN, I.; JO, E.H.; JEONG, B.R. Silicon promotes shoot proliferation and shoot growth of Salvia splendens under salt stress in vitro. Horticulture, Environment, and Biotechnology, v.54, p.311-318, 2013. DOI: 10.1007/s13580-013-0118-7.

TAHA, R.M.; WAFA, S.N. Plant regeneration and cellular behaviour studies in Celosia cristata Grown in vivo and in vitro. The ScientificWorld Journal, v.2012, art. 359413, 2012. DOI: 10.1100/2012/359413.

TAIZ, L.; ZEIGER, E. Fisiologia vegetal. 5.ed. Porto Alegre: Artmed, 2013. 918p.

TAMBOSI, G.; ROGGE-RENNER, G.D. Avaliação de métodos de esterilização, concentração de ágar e composição de meio de cultura para propagação in vitro de Pimpinella anisum (Linn.) Apiaceae. Semina: Ciências Biológicas e da Saúde, v.31, p.189194, 2010. DOI: 10.5433/1679-0367.2010v31n2p189.

TLAHUEXTL-TLAXCALTECA, C.; ÁVILA-SANCHEZ, J.M.; LESZCZYÑSKA-BORYS, H.L. Flores de corte y follaje en florerías y mercados de Puebla, México. Revista Chapingo Serie Horticultura, v.11, p.323-327, 2005. DOI: 10.5154/r. rchsh.2004.04.026.

VALLADARES, F.; GARCÍA-PLAZAOLA, J.I.; MORALES, F.; NIINEMETS, Ü. Photosynthetic responses to radiation. In: FLEXAS, J.; LORETO, F.; MEDRANO, H. (Ed.). Terrestrial photosynthesis in a changing environment: a molecular, physiological, and ecological approach. United Kigdom: Cambridge University, 2012. cap.16, p.241-260. DOI: 10.1017/ CBO9781139051477.020.

VASCONCELOS, A.G.V. de; TOMAS, L.F.; CAMARA, T.R.; WILLADINO, L. Hiperidricidade: uma desordem metabólica. Ciência Rural, v.42, p.837-844, 2012. DOI: 10.1590/S010384782012000500013.

WARHADE, M.I.; BADERE, R.S. Efficient micropropagation by multiple shoot induction through recurrent regeneration in Celosia cristata L. Indian Journal of Biotechnology, v.14, p.402-410, 2015.

$\overline{\text { Received on February 14, } 2017 \text { and accepted on June 1, } 2017}$

Pesq. agropec. bras., Brasília, v.53, n.1, p.30-41, Jan. 2018 DOI: 10.1590/S0100-204X2018000100004 